dr Bogumiła Konieczny-Rozenfeld

Wojskowa Akademia Techniczna w Warszawie

Biblioteka Główna

bogumila.konieczny-rozenfeld@wat.edu.pl

\title{
NIE TAKIE RODO STRASZNE. WYBRANE ZAGADNIENIA Z ZAKRESU OCHRONY DANYCH OSOBOWYCH W BIBLIOTECE
}

\author{
GDPR - NOT SUCH A SCARY PROCESS. SELECTED ISSUES \\ IN THE FIELD OF PERSONAL DATA PROTECTION AT THE LIBRARY
}

\begin{abstract}
$\mathrm{Z}$ dniem 25 maja 2018 r. weszły w życie nowe przepisy w zakresie ochrony danych osobowych, tzw. RODO. Zmieniają one podejście do ochrony osób fizycznych w związku z przetwarzaniem danych osobowych. Wejście w życie reformy systemu ochrony danych osobowych jest wyzwaniem dla wszystkich podmiotów, w tym bibliotek. W artykule omówiono niektóre zagadnienia generujące najczęstsze pytania i wątpliwości związane z wprowadzeniem RODO w bibliotekach. Szczegółowej analizie poddano pojęcie danych osobowych oraz interpretację przepisów dotyczących ochrony wizerunku. Omówiono także rejestr przewinień podlegających karom finansowym za naruszanie ochrony danych osobowych.
\end{abstract}

Słowa kluczowe: RODO, dane osobowe, kategorie danych osobowych, ochrona obrazu, kary administracyjne.

\begin{abstract}
On May 25, 2018, new regulations regarding the protection of personal data entered into force, the so-called GDPR (RODO). They change the approach to the processing of individuals' personal data. The entry into force of the reform of the personal data protection system is a challenge for all entities that process these data, including libraries. The article discusses some issues that generate the most common questions and concerns related
\end{abstract}


to the introduction of the GDPR in libraries. The concept of personal data and the interpretation of provisions regarding image protection are analyzed in detail. The record of offenses subject to financial penalties for violation of personal data protection is also discussed.

Keywords: GDPR (RODO), personal data, categories of personal data, image protection, administrative penalties.

\section{RODO w bibliotece - nowe podejście do przetwarzania danych}

W maju 2018 r., po dwuletnim okresie przygotowawczym, weszło w życie ogólne rozporządzenie o ochronie danych $\mathrm{RODO}^{1}$, zmieniające podejście w zakresie przetwarzania danych oraz dostosowanie dotychczasowych przepisów w zakresie bezpieczeństwa informacji. Każda, nawet najmniejsza biblioteka, powinna wdrożyć odpowiednie działania, które zabezpieczą dane osób fizycznych - czytelników, pracowników oraz firm współpracujących z biblioteką. Czy należy się obawiać nowego podejścia, nowej polityki $\mathrm{w}$ zakresie przetwarzania danych $\mathrm{w}$ pracy biblioteki? Na temat rewolucji, bądź ewolucji², jak to opisuje Sylwia Czub-Kiełczewska, w postrzeganiu zagadnień bezpieczeństwa i przetwarzaniu danych pojawiło się już sporo publikacji. Wydaje się, że dwa lata przystosowawcze umożliwiły dostosowanie i przygotowanie nowych procedur bibliotecznych, pozwalając tym samym uniknąć sytuacji problematycznych. Nowe przepisy wprowadziły szereg obowiązków, nowe rodzaje odpowiedzialności, a także dotkliwe sankcje finansowe. Prognozowane kary za działanie niezgodne z RODO, to miliony euro lub setki tysięcy złotych w zależności od podmiotu, który zostanie ukarany. Nowa ustawa przewiduje rozszerzające kategorie odpowiedzialności za naruszenia, wskazuje kierowników jednostek jako osoby odpowiedzialne bezpośrednio za poprawność przetwarzania danych osobowych, powołuje nowych inspektorów danych osobowych (IOD) oraz nakazuje przeprowadzanie audytów bezpieczeństwa i prowadzenie

1 Rozporządzenie Parlamentu Europejskiego i Rady (UE) 2016/679 z dnia 27 kwietnia 2016 r. $w$ sprawie ochrony osób fizycznych $w$ związku $z$ przetwarzaniem danych osobowych $i$ w sprawie swobodnego przepływu takich danych oraz uchylenia dyrektywy 95/46/ /WE (ogólne rozporządzenie o ochronie danych). Tryb dostępu: https://eur-lex.europa. eu/legal-content/PL/TXT/?uri=CELEX\%3A32016R0679 [22 października 2018].

2 S. Czub-Kiełczewska: OdliczaIODnie do RODO rozpoczęte... „Bibliotekarz” 2018, nr 2, s. 37-38. 
rejestrów ryzyka oraz naruszeń. To niektóre ze zmian, jakie należy wdrożyć w swojej organizacji.

Wydaje się, że wraz z wejściem obowiązku przestrzegania nowej ustawy tzw. RODO, wszystkie biblioteki dostosowały procedury upoważnień do przetwarzania danych, umów powierzenia, szkoleń podnoszących świadomość i wiedzę w tym zakresie, zarówno pracowników, jak i użytkowników. Wydaje się oczywistym, że w obecnej chwili stan znajomości i kompetencji dyrekcji i pracowników bibliotek nie powinien stanowić już źródła niepokoju i obaw związanych $\mathrm{z}$ wprowadzeniem systemu kar administracyjnych za naruszenie przepisów RODO. Wprowadzenie wszystkich wytycznych i ich właściwa interpretacja była procesem długim i trudnym. Dostosowanie praktycznej wiedzy w zakresie prawidłowego działania nowego rozporządzenia można ująć skrótowo w 10 najważniejszych punktach.

Po pierwsze, bardzo istotna jest bezpośrednia odpowiedzialność przetwarzającego dane. Za naruszenie przepisów o ochronie danych osobowych odpowiada szef firmy, jednostki, szkoły, urzędu. Odpowiedzialność jest bezpośrednia, a powołanie inspektora ochrony danych osobowych, nie zwalnia z tej odpowiedzialności. Rektor, dyrektor czy kierownik organizacji powinien być dobrze przygotowany do wdrożeń dyrektyw RODO. Kierownik organizacji odpowiada zarówno przed urzędem kontroli, jak i przed sądem cywilnym czy karnym. Nie może cedować tej odpowiedzialności na innych pracowników. Szczególną uwagę zwraca fakt, że odpowiedzialność karna dotyczy każdej osoby naruszającej przepisy w tym zakresie, w tym bibliotekarza. RODO wprowadza dotkliwe kary finansowe za brak wdrożenia i przestrzegania nowych przepisów dotyczących ochrony danych osobowych. Przewiduje się, że wysokość nakładanych kar będzie proporcjonalna do skali naruszenia przepisów. Odpowiedzialność karną można ponieść za przetwarzanie danych, pomimo że ich przetwarzanie jest niedopuszczalne, lub za przetwarzanie danych bez stosownych uprawnień. Ukaranym można zostać także za udaremnianie prowadzenia kontroli dotyczącej przestrzegania przepisów o ochronie danych osobowych ${ }^{3}$. Istotnym zagadnieniem jest bezpośrednia odpowiedzialność przetwarzającego dane.

Novum w działalności każdej firmy, w tym organów nadzorczych bibliotek każdego szczebla organizacji, jest powołanie Inspektora Ochrony Danych (IOD). Inspektor, to nowa osoba w organizacji, odpowiedzialna za bezpieczeństwo danych oraz za raportowanie naruszeń do urzędu

3 M. Sierpień: Jakq karę może zapłacić biblioteka za naruszenie ochrony danych osobowych. „Nowoczesna Biblioteka 3.0” 2018, nr 6, s 3-4. 
kontroli. Funkcja dotychczasowego administratora danych osobowych przestaje istnieć. Powołanie IOD jest obligatoryjne dla podmiotów, które prowadząc swoją działalność, przetwarzają dane, w których brak należytego zabezpieczenia może spowodować naruszenie praw i wolności osób fizycznych, a w szczególności, jeśli dotyczy nieletnich. Inspektor Ochrony Danych powinien wykazywać się wiedzą ekspercką w zakresie ochrony danych osobowych, aby odpowiednio kierować polityką bezpieczeństwa danych $\mathrm{w}$ organizacji. Inspektor jest osobą odpowiedzialną za szkolenia i podnoszenie świadomości pracowników w zakresie poprawności przetwarzania danych. Ma obowiązek zgłaszania wszelkich naruszeń bezpieczeństwa danych osobowych w czasie do 72 godzin od naruszenia, bezpośrednio do właściwego organu nadzoru. W niektórych przypadkach należy również poinformować o takim incydencie konkretne osoby, których dane „wyciekły”.

Kolejną zmianą, jaką wprowadziło RODO, jest dla Inspektorów Ochrony Danych obowiązek prowadzenia rejestru naruszeń oraz przeprowadzenie analizy ryzyka przetwarzania danych. Koniecznością jest opracowanie i wdrożenie w każdej firmie, także w bibliotece, procedur oraz środków zapewniających bezpieczeństwo przetwarzanych danych osobowych, w tym metod regularnego testowania i oceny ich. Rozporządzenie nie wskazuje wprost, jakie dokumenty, procedury i polityki należy wdrożyć. Należy pamiętać, że to podmiot musi się wykazać starannością w zabezpieczeniu tych procesów, aby podczas przetwarzania danych osobowych nie doszło do nieprawidłowości. Każda biblioteka musi w tym zakresie opracować i upublicznić swoim użytkownikom nowe klauzule informacyjne. RODO nie wymaga rejestracji zbiorów danych osobowych, nakłada natomiast obowiązek ich inwentaryzacji, polegający na prowadzeniu wewnętrznych rejestrów czynności przetwarzania danych, zawierający m.in. informacje takie jak: powody przetwarzania danych, kategorie podmiotów danych i danych osobowych, rejestry naruszeń, osoby odpowiedzialne za poszczególne procesy przetwarzania.

RODO przyznaje użytkownikom wiele nowych uprawnień, które muszą być respektowane przez biblioteki. Wśród uprawnień jest prawo do „bycia zapomnianym", czyli trwałe usunięcie danych osobowych przetwarzanych przez bibliotekę i dotyczy to informacji w formie cyfrowej, papierowej i kopii zapasowej. Warto też zwrócić uwagę na kolejny bardzo istotny punkt dotyczący przetwarzania danych osobowych dzieci, w tym upubliczniania wizerunku dziecka. Opiekunowie prawni dziecka mają pełne prawo wyrażenia zgody lub odmowy na wykorzystanie jego danych (w szczególności 
w usługach świadczonych elektronicznie). Pracownicy biblioteki muszą wiedzieć, że zgoda wyrażona przez dziecko może być nieważna, zwłaszcza jeżeli dotyczy celów marketingowych czy też aktywności dzieci w mediach społecznościowych.

\section{Dane osobowe - zwykłe i szczególne}

Opisując nowe podejście do rozporządzenia o ochronie danych należy zdefiniować pojęcie „dane osobowe”. Według słownika języka polskiego termin „dane” oznacza: rzeczy, fakty, informacje, wiadomości, ale też dane biograficzne, osobiste, personalne $e^{4}$. Pojęcie danych osobowych jest jedną z osi, wokół której zbudowane jest prawo ochrony danych osobowych. Wraz z rozwojem i upowszechnianiem się roli technologii informatycznych zmieniał się również zakres pojęcia danych osobowych. Rozwój technologiczny i informatyczny, spotęgował zagrożenia strefy prywatności człowieka, jaką stanowią jego dane osobowe. Zgodnie z art. 4 ust. 1 RODO „dane osobowe” to informacje o zidentyfikowanej lub możliwej do zidentyfikowania osobie fizycznej. Osobę można bezpośrednio lub pośrednio zidentyfikować w szczególności na podstawie identyfikatora takiego jak:

- imię i nazwisko;

- numer identyfikacyjny;

- dane o lokalizacji;

- identyfikator internetowy ${ }^{5}$ (adresy IP, identyfikatory plików cookie generowane przez ich urządzenia, aplikacje, narzędzia i protokoły czy też inne identyfikatory, generowane na przykład przez etykiety RFID ${ }^{6}$;

- jeden bądź kilka szczególnych czynników określających fizyczną tożsamość osoby fizycznej, a wśród nich tożsamość fizjologiczną, genetyczną, psychiczną, ekonomiczną, kulturową lub społeczną.

4 Słownik języka polskiego. Red. M. Szymczak. Warszawa 1978, s. 360.

5 Identyfikator internetowy. Zob. Portal o unijnym rozporządzeniu o ochronie danych osobowych. Tryb dostępu: https://gdpr.pl/dane-osobowe [22 października 2018].

6 RFID (ang. Radio-frequency identification) - technika wykorzystująca, w celu identyfikacji obiektu, fale radiowe do przesyłania danych oraz zasilania elektronicznego układu stanowiącego etykietę obiektu przez czytnik. Zob: M. Czerniawski: Prawne aspekty identyfikacji z użyciem fal radiowych (RFID). „Kwartalnik Prawa Publicznego” 2010, nr 3, s. 95-116. Tryb dostępu: http://bazhum.muzhp.pl/media/files/Kwartalnik_Prawa_Publicznego/Kwartalnik_Prawa_Publicznego-r2010-t10-n3/Kwartalnik_Prawa_Publicznego-r2010-t10-n3-s95-116/Kwartalnik_Prawa_Publicznego-r2010-t10-n3-s95-116. pdf [17 października 2018]. 
$\mathrm{Na}$ gruncie praktyki bibliotecznej istotne znaczenie mają zasady przetwarzania danych osobowych. Artykuł 5 RODO jasno określa, że wszelkie działania związane z przetwarzaniem danych powinny być rzetelne i zgodne z prawem. Zasady powinny być przejrzyste, wszelkie komunikaty związane z przetwarzaniem należy sformułować jasnym i prostym językiem. Zasada ta dotyczy w szczególności informowania użytkowników bibliotek o tożsamości administratora i celach przetwarzania oraz innych informacji zapewniających przejrzystość przetwarzania czy np. czasu przechowywania danych.

W regulacji wprowadzone zostają następujące zasady:

- legalności, rzetelności i przejrzystości;

- ograniczenia celu;

- minimalizacji danych;

- prawidłowości (poprawności danych);

- ograniczenia przechowywania;

- integralności i poufności (bezpieczeństwa informacji);

- rozliczalności.

W bibliotekach przetwarzane są dane zwykłe. Ważne jest, aby osoby przetwarzające dane $\mathrm{w}$ codziennej praktyce bibliotecznej miały świadomość, czym są dane osobowe szczególne, zwane w poprzedniej ustawie danymi wrażliwymi. Szczególne dane osobowe to takie, które zawierają informacje o pochodzeniu rasowym lub etnicznym, o poglądach politycznych, o przekonaniach religijnych lub światopoglądowych, o przynależności do związków zawodowych, danych genetycznych, biometrycznych, dotyczących zdrowia czy seksualności lub orientacji seksualnej. W odniesieniu do tych danych ustanowiono generalny zakaz ich przetwarzania.

\section{Ochrona danych osobowych w bibliotece jako miejscu pracy}

Nowe podejście do przetwarzania danych w bibliotece dotyczy zarówno jej użytkowników, jak i pracowników. Prawa w zakresie ochrony danych pracowników już zatrudnionych zabezpieczają umowy o pracę, klauzule zawierające zgody na przetwarzanie danych, czy upoważnienia na przetwarzanie danych przez pracowników. Należy zwrócić również uwagę na zasady przetwarzania w ramach rekrutacji na nowe stanowiska biblioteczne. Proces poszukiwania nowych pracowników wiąże się z pozyskiwaniem danych osobowych z dokumentów rekrutacyjnych. Dane przedstawiane w aplikacjach rekrutacyjnych powinien charakteryzować minimalizm. Potencjalny pracodawca powinien przetwarzać tylko takie dane, które są niezbędne ze 
względu na ich cel, jakim jest zatrudnienie nowego bibliotekarza. Informacje przekazywane przez pracownika powinny być konkretne i odpowiadające wymogom oferty pracy. Dyrektor biblioteki bądź organ kierujący biblioteką musi poinformować kandydatów do pracy o przetwarzaniu ich danych osobowych, określając cel przetwarzania, czas trwania celu, prawa dostępu do danych, otrzymania ich kopii, sprostowania danych, czy cofnięcia zgody na przetwarzanie danych. Zdarza się, że poszukujący pracy wysyłają dokumenty rekrutacyjne, choć nie jest prowadzony nabór na stanowiska. Dyrektor biblioteki powinien w takiej sytuacji usunąć dokumenty aplikacyjne z poczty elektronicznej. Nie można też zatrzymywać tych dokumentów na poczet przyszłych i nieokreślonych w czasie innych rekrutacji do pracy w bibliotece. Niedopuszczalna jest także praktyka pozyskiwania danych o kandydacie do pracy z portali społecznościowych czy od poprzednich pracodawców. Taki sposób pozyskiwania informacji jest niezgodny z prawem. Kandydat do pracy nie wie, jakie informacje podlegają przetwarzaniu przez przyszłego, potencjalnego pracodawcę. Mimo, iż portale społecznościowe zawierają mnóstwo danych przekazywanych przez właścicieli kont, to pracodawca nie jest uprawniony do przetwarzania takich danych. Kandydat do pracy nie powinien być oceniany na podstawie informacji prezentowanych $\mathrm{w}$ mediach społecznościowych. Rejestr czynności, danych prezentowanych w procesie rekrutacji, ich zakresów, celu i interpretacji szczegółowo omawia Poradnik RODO, wydany w 2018 r. przez Urząd Ochrony Danych Osobowych ${ }^{7}$.

\section{Wizerunek i monitoring wizyjny jako kategoria danych}

Istotnym zagadnieniem $\mathrm{w}$ ochronie przetwarzania danych $\mathrm{w}$ bibliotece jest wizerunek osoby - zarówno czytelnika, użytkownika czy pracownika biblioteki. Prawo do wizerunku podlega ochronie na gruncie Ustawy $z$ dnia 4 lutego 1994 r. o prawie autorskim $i$ prawach pokrewnych ${ }^{8}$. Nie można rozpowszechniać cudzego wizerunku bez zgody osoby na nim przedstawionej, z wyłączeniem trzech wyjątków: po pierwsze osoba, której wizerunek ma być rozpowszechniony, jest osobą powszechnie znaną, a jej wizerunek utrwalono $\mathrm{w}$ związku $\mathrm{z}$ pełnieniem przez nią funkcji

7 Ochrona danych osobowych w miejscu pracy. Poradnik dla pracodawców. Urząd Ochrony Danych Osobowych. Warszawa, październik 2018.

8 Ustawa z dnia 4 lutego 1994 r. o prawie autorskim i prawach pokrewnych. Dz.U. 1994, Nr 24, poz. 83. 
publicznych (w szczególności politycznych, społecznych, zawodowych); a po wtóre, wizerunek osoby stanowi jedynie szczegół całości takiej jak: zgromadzenie, krajobraz, publiczna impreza. Ostatnim warunkiem jest fakt, że osoba otrzymała umówioną zapłatę za pozowanie. Jeśli w galeriach zdjęć z imprez bibliotecznych, kronice, na wystawach bibliotecznych pojawia się wizerunek dziecka, które nie ukończyło 16. roku życia, to nie może ono samodzielnie wyrazić zgody na publikację wizerunku - muszą to w jego imieniu zrobić rodzice lub opiekunowie prawni ${ }^{9}$.

Kolejnym zagadnieniem w nowej ustawie o ochronie danych osobowych jest monitoring wizyjny. Zasady korzystania $\mathrm{z}$ monitoringu wizyjnego opisuje RODO oraz reguluje Kodeks pracy ${ }^{10}$, gdzie zgodnie $\mathrm{z}$ art. $22^{2}$ i art. $22^{3}$ pracodawca może prowadzić monitoring wizyjny, jeżeli jest to niezbędne do zapewnienia bezpieczeństwa pracowników lub ochrony mienia. Monitoring może obejmować teren biblioteki oraz obszar wokół biblioteki. To jedyne przesłanki uzasadniające instalację kamer. Nie jest to natomiast dozwolone kontrolowanie przy użyciu monitoringu wizyjnego, sposobu wykonywania pracy. Monitoring, co do zasady, nie może być instalowany $\mathrm{w}$ pomieszczeniach sanitarnych, szatniach, stołówkach oraz palarni lub pomieszczeniach udostępnianych zakładowej organizacji związkowej. W ramach monitoringu wizyjnego przetwarzane są dane osobowe w postaci wizerunku. RODO nie zawiera regulacji dotyczącej możliwości stosowania monitoringu w zakładzie pracy, jednakże przepisy w tym zakresie mają zostać wprowadzone do kodeksu pracy. Zapis z monitoringu jest „daną osobową" zwykłą, oznaczającą informacje o zidentyfikowanej lub możliwej do zidentyfikowania osobie fizycznej. Bez wątpienia nagranie z kamery, na którym został utrwalony wizerunek określonej osoby, pozwala na jej zidentyfikowanie (określenie jej tożsamości). W związku z tym konieczne jest ustalenie powiązań pomiędzy monitoringiem wizyjnym a ochroną danych osobowych. Zapis RODO nie precyzuje pełnego unormowania zapisu monitoringu wizyjnego. W stosunku do danych pozyskanych za pomocą kamer przemysłowych należy stosować wszystkie zasady, o których mowa w RODO, zwłaszcza dotyczące obowiązku informacyjnego

9 Art. 8. Rozporzadzenia Parlamentu Europejskiego i Rady(UE) 2016/679 z dnia 27 kwietnia 2016 r. w sprawie ochrony osób fizycznych w związku z przetwarzaniem danych osobowych iw sprawie swobodnego przepływu takich danych oraz uchylenia dyrektywy 95/46/WE (ogólne rozporządzenie o ochronie danych). Tryb dostępu: https://eur-lex.europa.eu/legal-content/PL/TXT/?uri=CELEX\%3A32016R0679 [22 października 2018].

10 Kodeks pracy. Ustawa. Dz.U. 2018, poz. 917, 1000, 1076, 1608, 1629. 
oraz regulujące prawa osób, których dane dotyczą. Obiektem wideofilmowania przemysłowego w bibliotekach nie jest osoba czy grupa osób, lecz określone miejsce $\mathrm{w}$ celu wczesnego wykrycia niepożądanych zdarzeń i możliwości podjęcia odpowiednich działań prewencyjnych. Osoby, które potencjalnie mogą się znaleźć $\mathrm{w}$ takim obszarze powinny być poinformowane, że wejście $\mathrm{w}$ taki obszar jest równoznaczne $\mathrm{z}$ wyrażeniem przez tę osobę zgody na przetwarzanie jej danych w zakresie wizerunku.

\section{Rejestr przewinień, czyli co według RODO podlega karze finansowej}

RODO szczegółowo określa w art. 83 zakres naruszeń, za które przyznawane mogą być nakładane kary finansowe oraz podkreśla, że kary te powinny być za każdym razem skuteczne, proporcjonalne oraz odstraszające. Regulacja określa przesłanki wpływające na decyzję o wysokości i zasadności grzywny organu nadzorczego, nakładającego karę finansową. Wśród nich znajdują się m.in.:

- istotność naruszenia (rozmiar powstałych szkód, liczba osób przez nie dotkniętym);

- celowość lub umyślność wykroczenia;

- fakt, czy administrator danych osobowych podejmował próbę naprawienia szkód;

- występowanie innych naruszeń w przeszłości;

- fakt, czy naruszenie zostało dobrowolnie zgłoszone organowi nadzorczemu.

Na jakie kary administracyjne może być narażony bibliotekarz za naruszenie przepisów RODO? Kary pieniężne przewidziane dla sektora publicznego to kwota do 10 tys. zł dla instytucji państwowych i samorządowych i do 100 tys. zł dla jednostek sektora finansów publicznych.

Wśród podstawowych przewinień podlegających karom finansowym wymienić należy:

- przetwarzanie danych bez zgody osoby, której dane dotyczą;

- niedopełnienie obowiązku informacyjnego wobec osoby, której przetwarzane dane dotyczą;

- nieprzestrzeganie nakazu, tymczasowego lub ostatecznego ograniczenia przetwarzania lub przepływu danych;

- nieuwzględnienie ochrony danych w fazie projektowania, co w praktyce oznacza, że przed dokonaniem pierwszych czynności przetwarzania administrator jest zobowiązany do uwzględnienia i zaplanowania 
kwestii związanych z ochroną danych osobowych. Projektując produkt lub usługę należy więc mieć na uwadze to, w jaki sposób zapewnione zostanie prawidłowe stosowanie RODO;

- wybór podmiotu przetwarzającego, który nie spełnia wymogów technicznych, aby przetwarzać powierzone mu dane.

\section{Podsumowanie}

Czy należy bać się RODO w praktyce i działalności bibliotek. Zmiany zobowiązały kierownictwo bibliotek do dostosowywania systemów przechowywania danych osobowych. Oczekuje się znajomości w tym zakresie dyrektyw RODO, Kodeksu pracy i Ustawy o prawie autorskim. Ponadto RODO nakłada obowiązek powołania IOD w każdym zakładzie pracy, opracowania przez niego polityki bezpieczeństwa danych, oceny ryzyka w zakresie przetwarzania danych. Pod kierownictwem IOD powinny być tworzone upoważnienia do przetwarzania danych, zgodnie z zapisem prawnym, klauzule informacyjne czy umowy powierzenia.

Zgodnie z zaproponowanym tytułem artykułu Nie takie RODO straszne, przyjmując do kodeksu postępowania kilka priorytetowych zadań, strach przed niewiadomą zostanie całkowicie zminimalizowany. Rejestr podstawowych zasad $\mathrm{w}$ zakresie przetwarzania danych w bibliotece, a będących w zgodzie z RODO:

- minimalizacja posiadanych danych osobowych - nie należy ich gromadzić w nadmiarze;

- stosowanie umów powierzenia danych osobowych;

- nadawanie upoważnień do przetwarzania danych osobowych pracownikom, którzy takie dane przetwarzają;

- zwiększenie świadomości pracowników - szkolenia!

- nieudostępnianie bez zgody danych osobowych oraz czyjegoś wizerunku;

- informacja o użyciu wizerunku;

- udostępnianie wizerunku dziecka poniżej 16. roku życia, wyłącznie za zgodą rodzica/opiekuna;

- weryfikacja poprawności wpisanego adresu e-maila, a przy masowej wysyłce korespondencji korzystanie z funkcji ukrywania poszczególnych odbiorców wiadomości;

- spełnianie obowiązku informacyjnego - poinformowanie użytkowników biblioteki o tym, jakie dane osobowe są przetwarzane, 
poinformowanie o przysługujących prawach oraz informacja, kto jest administratorem danych;

- opracowanie procedury ochrony danych osobowych.

Ponadto zawsze, w przypadku wątpliwości, należy zwrócić się do Inspektora Ochrony Danych z wnioskiem o audyt procedur.

\section{Bibliografia}

1. Czerniawski M.: Prawne aspekty identyfikacji z użyciem fal radiowych (RFID). „Kwartalnik Prawa Publicznego” 2010, nr 3, s. 95-116. Tryb dostępu: http:// bazhum.muzhp.pl/media/files/Kwartalnik_Prawa_Publicznego/Kwartalnik_ Prawa_Publicznego-r2010-t10-n3/Kwartalnik_Prawa_Publicznego-r2010-t10-n3-s95-116/Kwartalnik_Prawa_Publicznego-r2010-t10-n3-s95-116.pdf [17 października 2018].

2. Czub-Kiełczewska S.: Czy biblioteki moga być zwolnione z obowiązków wynikajacych z RODO. „Bibliotekarz” 2018, nr 4, s. 38-39.

3. Czub-Kiełczewska S.: Odliczanie do RODO rozpoczęte.... „Bibliotekarz” 2018, nr 2, s. 37-38.

4. Identyfikator internetowy. Tryb dostępu: https://gdpr.pl/dane-osobowe [22 października 2018].

5. Kodeks pracy. Ustawa. Dz.U. 2018, poz. 917, 1000, 1076, 1608, 1629. Kancelaria Sejmu, s. 11-12/157.

6. Koziara A.: Reorganizacja ustug bibliotecznych a wymagania wynikajace $z$ Rozporzadzenia Parlamentu Europejskiego w prawie ochrony danych osobowych. W: Ewolucja nowych przestrzeni bibliotecznych. Od założeń do praktyki. Olsztyn 2018, s. 67-76.

7. Lubasz D.: Zmiany w zakresie ochrony danych osobowych. Warszawa 2018.

8. Ochrona danych osobowych $w$ miejscu pracy. Poradnik dla pracodawców. Urząd Ochrony Danych Osobowych. Warszawa, październik 2018.

9. Pióro B.: RODO. Ochrona danych osobowych. Przewodnik po zmianach. Warszawa 2018.

10. Rozporzadzenie Parlamentu Europejskiego i Rady (UE) 2016/679 z dnia 27 kwietnia 2016 r. w sprawie ochrony osób fizycznych $w$ związku $z$ przetwarzaniem danych osobowych i $w$ sprawie swobodnego przepływu takich danych oraz uchylenia dyrektywy 95/46/WE (ogólne rozporządzenie o ochronie danych). Tryb dostępu: https://eur-lex.europa.eu/legal-content/PL/TXT/?uri=CELEX\%3A32016R0679 [22 października 2018].

11. Sierpień M.: Jaką karę może zapłacić biblioteka za naruszenie ochrony danych osobowych. „Nowoczesna Biblioteka 3.0” 2018, nr 6, s. 3-4.

12. Słownik języka polskiego. Red. M. Szymczak. Warszawa 1978, s. 360.

13. Ustawa $z$ dnia 4 lutego 1994 r. o prawie autorskim i prawach pokrewnych. Dz.U. 1994, Nr 24, poz. 83. Kancelaria Sejmu, s. 46. 